\title{
CD8+CD122+ T-cells: a newly emerging regulator with central memory cell phenotypes
}

\author{
Junfeng Liư ${ }^{1}$, Dacan Chen ${ }^{1}$, Golay D. Nie ${ }^{2}$ and Zhenhua Dai ${ }^{1 *}$ \\ 'Section of Immunology, Division of Dermatology, Second Affiliated Hospital, Guangdong Provincial Academy of Chinese \\ Medical Sciences, Guangzhou University of Chinese Medicine, Guangzhou, China, ${ }^{2}$ School of Medicine, University of Texas \\ Medical Branch (UTMB), Galveston, TX, USA
}

OPEN ACCESS

Edited by:

Gilles Blancho,

University Hospital

of Nantes, France

Reviewed by:

Nicolas Degauque, INSERM, France

Amir Ahmed Toor,

Virginia Commonwealth

University, USA

*Correspondence:

Zhenhua Dai,

Section of Immunology, Guangdong

Academy of Chinese Medical

Sciences, 55 Nei Huan Xi Lu, College

Town, Guangzhou, Guangdong

510006, China

zdai2009@hotmail.com

Specialty section:

This article was submitted to

Alloimmunity and Transplantation,

a section of the journal

Frontiers in Immunology

Received: 29 June 2015 Accepted: 10 September 2015 Published: 19 October 2015

Citation:

Liu J, Chen D, Nie GD and Dai Z (2015) CD8+CD122+ T-cells: a newly emerging regulator with central memory cell phenotypes.

Front. Immunol. 6:494. doi: 10.3389/fimmu.2015.00494
CD8 ${ }^{+} \mathrm{CD} 122^{+}$T-cells have been traditionally described as antigen-specific memory T-cells that respond to previously encountered antigens more quickly and vigorously than their naïve counterparts. However, mounting evidence has demonstrated that murine CD8 ${ }^{+} \mathrm{CD} 122^{+}$T-cells exhibit a central memory phenotype (CD44 $\left.{ }^{\text {high }} \mathrm{CD} 62 \mathrm{~L} \mathrm{~L}^{\text {high }}\right)$, regulate T cell homeostasis, and act as regulatory T-cells (Treg) by suppressing both autoimmune and alloimmune responses. Importantly, naturally occurring murine CD8 ${ }^{+} \mathrm{CD} 122^{+}$Tregs are more potent in immunosuppression than their $\mathrm{CD} 4{ }^{+} \mathrm{CD} 25^{+}$counterparts. They appear to be acting in an antigen-non-specific manner. Human $\mathrm{CD} 8^{+} \mathrm{CXCR} 3^{+}$T-cells are the equivalent of murine CD8 ${ }^{+} \mathrm{CD} 122^{+}$Tregs and also exhibit central memory phenotypes. In this mini-review article, we will summarize recent progresses in their phenotypes, homeostatic expansion, antigen-specificity, roles in the suppression of alloimmune and autoimmune responses, and the mechanisms underlying their inhibitory function.

Keywords: regulatory $\mathrm{T}$-cells, $\mathrm{CD} 8^{+} \mathrm{CD} 122^{+} \mathrm{T}$-cells, immunoregulation, allograft survival, transplant tolerance, memory T-cells

\section{Introduction}

Upon reencounter with previously recognized antigens, memory T-cells respond more rapidly and vigorously than their naïve counterparts. They are somewhat resistant to immunosuppression, such as costimulatory blockade $(1,2)$. Memory T-cells can rapidly trigger alloimmune responses through the production of various inflammatory cytokines (3). Previous studies have also shown that early infiltration of $\mathrm{CD}^{+}$memory T-cells into allografts, including hearts, kidneys, and livers, facilitates allograft rejection and presents a hurdle to achieving long-term allograft survival (4-6). Therefore, they are generally considered as a major barrier to long-term allograft survival or tolerance (7). In particular, $\mathrm{CD} 8{ }^{+} \mathrm{CD} 122^{+} \mathrm{T}$-cells have previously been described as antigen-specific memory T-cells (8-10). However, emerging evidence has shown that central memory CD8 $8^{+} \mathrm{CD} 122^{+} \mathrm{T}$-cells $\left(\mathrm{CD} 44^{\text {high }}{ }^{\mathrm{CD}} 62 \mathrm{~L}^{\text {high }}\right)$ also play a role in regulating $\mathrm{T}$ cell homeostasis and serve as regulatory $\mathrm{T}$-cells (Tregs). Since original studies revealed that $\mathrm{CD}^{+} \mathrm{T}$-cells exhibit Treg properties (11-13), more and more studies have confirmed their immunosuppressive activities. Suzuki's research group has provided the early evidence that $\mathrm{CD} 8{ }^{+} \mathrm{CD} 122^{+} \mathrm{T}$-cells maintain $\mathrm{T}$ cell homeostasis (14), whereas more recent studies have suggested that $\mathrm{CD} 8{ }^{+} \mathrm{CD} 122^{+} \mathrm{T}$-cells are Tregs that suppress conventional

Abbreviations: EAE, experimental autoimmune encephalomyelitis; NO, nitric oxide; PD-1, programed death-1; Treg, regulatory $\mathrm{T}$ cell. 
$\mathrm{T}$ cell responses (14-20) and control autoimmune diseases $(21,22)$. We have found that memory $\mathrm{CD}^{+} \mathrm{CD}^{2} 22^{+} \mathrm{T}$-cells as well as bystander central memory $\mathrm{CD}^{+} \mathrm{T}$-cells are also Tregs that inhibit murine allograft rejection $(23,24)$. Moreover, others have shown that central memory $\mathrm{CD} 8^{+} \mathrm{T}$-cells mediate lung allograft acceptance (25). Therefore, $\mathrm{CD} 8^{+} \mathrm{CD} 122^{+}$Tregs may correspond to their $\mathrm{CD} 4^{+} \mathrm{CD} 25^{+} \mathrm{FoxP} 3^{+}$counterparts since $\mathrm{CD} 122$ is $\beta$ subunit of IL-2 receptor, whereas CD25 is an $\alpha$ subunit of the same receptor on $\mathrm{T}$ cells (26). More importantly, we have recently demonstrated that $\mathrm{CD} 8^{+} \mathrm{CD} 122^{+}$Tregs are more potent in their suppression of allograft rejection than their $\mathrm{CD} 4^{+} \mathrm{CD} 25^{+}$ counterparts (27). Hence, not only are memory $\mathrm{CD} 8^{+} \mathrm{CD} 122^{+}$ T-cells Tregs but can also boost the strength of Treg-mediated regulation.

Although $\mathrm{CD}^{+} \mathrm{CD} 122^{+}$Tregs may regulate immune responsiveness by production of IL-10, TGF $\beta 1$, and IFN $\gamma$, the exact mechanisms underlying their suppression are still largely unknown. More studies are required to fully understand their mechanisms and clearly distinguish between effectors and regulators that originate from memory $\mathrm{CD} 8{ }^{+} \mathrm{CD} 122^{+} \mathrm{T}$-cells, although $\mathrm{PD}-1$ expression recently has been shown to define $\mathrm{CD} 8{ }^{+} \mathrm{CD} 122^{+} \mathrm{T}$-cells as the memory versus Tregs (24). In this mini-review article, we will briefly summarize new progresses in their phenotypes, antigen specificity, roles in the suppression of alloimmune and autoimmune responses, and immune mechanisms underlying their inhibitory function.

\section{CD8 ${ }^{+}$CD122 ${ }^{+}$Treg Phenotypes}

Mounting evidence has suggested that $\mathrm{CD} 8{ }^{+} \mathrm{CD} 122^{+} \mathrm{T}$-cells are Tregs, which can suppress both autoimmunity and alloimmunity. They exhibit memory-like $\mathrm{T}$ cell phenotypes with regulatory functions. Murine $\mathrm{CD} 8{ }^{+} \mathrm{CD} 122^{+}$Tregs express CD122 (IL-2R $\beta$ ) and CXCR3, but not CD25, whereas their $\mathrm{CD}^{+} \mathrm{CD} 25^{+}$counterparts do not express CD122. $\mathrm{CD}^{+} \mathrm{CD} 122^{+}$Tregs are also $\mathrm{CD} 44^{\text {high }}, \mathrm{CD}^{2} 2 \mathrm{~L}^{\text {high }} \mathrm{CCR}^{+}$, and largely $\mathrm{CD}_{127^{-}}(24,28)$. However, CD8 ${ }^{+} \mathrm{CD} 122^{+}$Tregs are FoxP3-negative (24), indicating that they are a different subset from inducible $\mathrm{CD}^{+} \mathrm{FoxP}^{+}$Tregs (29). Memory-like $\mathrm{CD}^{+} \mathrm{CD} 122^{+} \mathrm{T}$-cells, which also express CD38, suppress $\mathrm{CD}^{+}{ }^{+} \mathrm{T}$-cell activation (30), whereas another subset of CD8 ${ }^{+}$ Tregs carry both CD122 surface marker and the class-I MHC receptor Ly49 (21). We have previously shown that PD-1 expression defines $\mathrm{CD}^{+} \mathrm{CD} 122^{+}$T-cells as Tregs versus memory T-cells (24).

Human equivalent of murine $\mathrm{CD} 8^{+} \mathrm{CD} 122^{+}$Tregs has also recently been characterized. They exhibit an in vitro suppressive property with phenotypes of $\mathrm{CD} 8^{+} \mathrm{CXCR} 3^{+} \mathrm{CD} 45 \mathrm{RA}^{-}$ and largely $\mathrm{CD}_{2} \mathrm{~L}^{+}$or $\mathrm{CCR}^{+}$, but do not express $\mathrm{CD} 122$ (31). However, it remains to be defined if CXCR3 expression alone can distinguish memory from regulatory human $\mathrm{CD}^{+} \mathrm{T}$-cells since effector $\mathrm{CD}^{+} \mathrm{T}$-cells may also express CXCR3. Taken together, both murine $\mathrm{CD}^{+} \mathrm{CD} 122^{+}$and human $\mathrm{CD}^{+}{ }^{+} \mathrm{CXCR} 3^{+}$Tregs exhibit the phenotypes of central memory T-cells.

\section{Age-Associated Distribution and Naturally Arising Features of Murine CD8 ${ }^{+} \mathrm{CD} 122^{+}$ Tregs}

The percentages of $\mathrm{CD} 122^{+} \mathrm{T}$-cells within $\mathrm{CD}^{+}$population fluctuate between 10 and $50 \%$, depending on mouse age. Overall, the percentages of $\mathrm{CD} 122^{+} \mathrm{T}$-cells in $\mathrm{CD} 8^{+}$population are very high in young mice, reduced to the lowest level of $\sim 10 \%$ at the age of $8-10$ weeks, and then increased with aging, exhibiting a pattern of two age-related phases (14). A high rate of $\mathrm{CD} 8{ }^{+} \mathrm{CD} 122^{+} \mathrm{T}$-cells in young mice may represent a regulatory cell component since previous studies and ours have proved that these cells derived from young mice are indeed Tregs, whereas the increased number of $\mathrm{CD} 8^{+} \mathrm{CD} 122^{+} \mathrm{T}$-cells at old age could be due to the increase in memory $\mathrm{CD} 8{ }^{+} \mathrm{CD} 122^{+}$ $\mathrm{T}$-cells. It remains to be determined if the latter are regulatory or memory T-cells and if they contain both components. On the other hand, $\mathrm{CD} 8{ }^{+} \mathrm{CD} 122^{+} \mathrm{T}$-cells that are proved to be Tregs have been isolated, to our knowledge, from naïve mice, suggesting that they are indeed naturally arising cells. However, it is unknown whether $\mathrm{CD} 8^{+} \mathrm{CD} 122^{+}$Tregs can be induced in vitro and in vivo. It is also unclear if they exhibit the same phenotypes upon expansion in vitro or in vivo. These questions warrant further investigations given that $\mathrm{CD} 8^{+} \mathrm{CD} 122^{+}$Tregs are more efficient but yet less studied than conventional $\mathrm{CD} 4^{+} \mathrm{CD} 25^{+}$ Tregs.

\section{Homeostasis and Expansion of Memory- Like CD8+CD122+ ${ }^{+}$Tregs}

IL-15 is essential for the generation and survival of memory $\mathrm{CD}^{+}$T-cells $(32,33)$ while administration of recombinant IL-15 significantly augments their numbers $(8,34)$. We have demonstrated that administration of IL-15 expands adoptively transferred $\mathrm{CD}^{+} \mathrm{CD} 122^{+}$Tregs and enhances their suppression of allograft rejection (27). We have also found that IL-15 promotes their expansion in vitro as well, suggesting that IL-15 provides a critical signal that drives homeostatic expansion of memory-like murine $\mathrm{CD} 8{ }^{+} \mathrm{CD} 122^{+}$Tregs. However, it remains to be defined if IL-15 also drives homeostatic expansion of human $\mathrm{CD}^{+}{ }^{+} \mathrm{CXCR}^{+}$Tregs. IL-15 may not do so since they do not express CD122. In order to enhance Treg suppression in a clinic setting, further studies are warranted to identify signals that are required for homeostatic expansion of human $\mathrm{CD}^{+} \mathrm{CXCR}^{+}$ Tregs.

Since IL-15 can expand both memory $\mathrm{CD}^{+}$T-cells and $\mathrm{CD}^{+} \mathrm{CD} 122^{+}$Tregs, it may act as a double-edged sword in the face of an allograft. It would be difficult to use IL-15 to promote $\mathrm{CD}^{+} \mathrm{CD} 122^{+}$Treg-mediated graft acceptance without expanding memory $\mathrm{CD}^{+} \mathrm{T}$-cells. Recent studies have shown that administration of IL-15 enhances anti-tumor immunity when blocking $\mathrm{CD}^{+} \mathrm{CD} 122^{+}$Treg function (35). In those studies, IL-15 enhanced memory CD8 ${ }^{+} \mathrm{T}$-cell function, but not $\mathrm{CD} 8^{+} \mathrm{CD} 122^{+}$ Treg suppression, given that Tregs were inhibited by PD-1 signaling blockade. In a transplant setting, however, we need to boost the Treg suppression. We have previously succeeded in utilizing low 
doses of IL-15 to promote adoptively transferred CD8 ${ }^{+} \mathrm{CD} 122^{+}$ Treg suppression of allograft rejection (27), indicating that when $\mathrm{CD}^{+} \mathrm{CD} 122^{+}$Tregs are transferred in large numbers, IL-15 likely promotes the expansion of more $\mathrm{CD} 8{ }^{+} \mathrm{CD} 122^{+}$Tregs than endogenous memory $\mathrm{CD}^{+} \mathrm{T}$-cells.

\section{Is CD8 ${ }^{+}$CD122 ${ }^{+}$Treg-Mediated Suppression Antigen-Specific?}

It remains to be defined if the immunosuppression mediated by murine $\mathrm{CD}^{+} \mathrm{CD} 122^{+}$Tregs is antigen specific. Recent studies have shown that $\mathrm{CD} 8^{+} \mathrm{CD} 122^{+}$Tregs exhibit CDR3 sequences of $\mathrm{T}$-cell receptor $\beta$ chain (36), and that the distribution of the CDR3 length is following a Gaussian-like one, except for Vb13. Based on this original study, it is possible that murine $\mathrm{CD} 122^{+} \mathrm{CD}^{+} \mathrm{T}$-cells are not selected in the thymus. Moreover, we have demonstrated that bystander memory $\mathrm{CD}^{+} \mathrm{T}$-cells with central memory phenotypes can inhibit allograft rejection in an antigen-non-specific manner (23). We have also shown that $\mathrm{CD} 8^{+} \mathrm{CD} 122^{+}$Treg-mediated suppression in vitro is donor-non-specific (24), supporting a finding by others that memory-like $\mathrm{CD} 8^{+} \mathrm{CD} 38^{+} \mathrm{T}$-cells suppress $\mathrm{CD}^{+} \mathrm{T}$ cell activation in an antigen-independent fashion (30). Therefore, it is possible that their suppression of immune responses is not antigen specific.

\section{CD8 $^{+}$CD122 ${ }^{+}$Tregs Inhibit Immune Responses in Animal Models of Diseases}

Early evidence has shown that $\mathrm{CD}^{+} \mathrm{CD} 122^{+}$Tregs regulate $\mathrm{T}$ cell homeostasis (14), whereas recent studies have suggested that they play an important role in the suppression of autoimmune responses. Transfer of $\mathrm{CD} 8^{+} \mathrm{CD} 122^{+}$Tregs significantly improved clinical symptoms of experimental autoimmune encephalomyelitis (EAE) (37), whereas IL-15-dependent $\mathrm{CD}^{+} \mathrm{CD} 122^{+}$Tregs also ameliorated EAE by suppressing IL-17 production (38). Dendritic cells (DCs) expressing B7-H1 molecule recruited $\mathrm{CD} 8{ }^{+} \mathrm{CD} 122^{+}$Tregs, which in turn suppressed the onset of EAE (39). CD ${ }^{+} \mathrm{CD} 38^{+} \mathrm{CD} 122^{+}$Tregs inhibited effector $\mathrm{CD}^{+}{ }^{+} \mathrm{T}$-cell activation and mitigated murine EAE by delaying the disease occurrence (30). Studies using HLA-DR3 transgenic mice also demonstrated that $\mathrm{CD} 8{ }^{+} \mathrm{CD} 122^{+} \mathrm{T}$-cells could regulate EAE (22). Depleting $\mathrm{CD} 8^{+} \mathrm{CD} 122^{+} \mathrm{T}$-cells augmented the incidence of autoimmune Graves' hyperthyroidism (40). Interestingly, $\mathrm{CD} 8^{+} \mathrm{CD} 122^{+}$and $\mathrm{CD} 4^{+} \mathrm{CD} 25^{+}$ Tregs cooperatively suppressed colitis mediated by $\mathrm{CD} 4^{+}$ T-cells (19), whereas the systemic lupus erythematosus-like disease in B6-Yaa mutant mice was associated with a defect in $\mathrm{CD}^{+} \mathrm{CD} 122^{+} \mathrm{T}$-cells (21). Therefore, it has been clear that $\mathrm{CD}^{+} \mathrm{CD} 122^{+}$Tregs play an essential role in the suppression of various experimental autoimmune diseases.

Emerging evidence has shown that memory-like $\mathrm{CD}^{+} \mathrm{CD} 122^{+}$Tregs can also suppress alloimmune responses and allograft rejection. We have unveiled the first evidence that $\mathrm{CD} 8{ }^{+} \mathrm{CD} 122^{+}$Tregs suppress allograft rejection, whereas their $\mathrm{PD}-1^{+}$component is more efficient than unfractionated
$\mathrm{CD}^{+} \mathrm{CD} 122^{+}$Treg population (24). Therefore, both $\mathrm{CD}^{+} \mathrm{CD} 25^{+}$and $\mathrm{CD} 8{ }^{+} \mathrm{CD} 122^{+}$T-cells are Tregs that can inhibit allograft rejection. In order to seek more efficient Treg suppression for potential clinical applications, we determined the efficacy of $\mathrm{CD} 8^{+} \mathrm{CD} 122^{+}$versus $\mathrm{CD} 4^{+} \mathrm{CD} 25^{+}$Tregs in their suppression of allograft rejection. We found that $\mathrm{CD} 8^{+} \mathrm{CD} 122^{+}$ Tregs were actually more potent in suppression of allograft rejection and underwent faster homeostatic proliferation in vivo than their $\mathrm{CD} 4{ }^{+} \mathrm{CD} 25^{+}$counterparts (27). Moreover, they also were more effective in the suppression of in vitro $\mathrm{T}$ cell proliferation than their $\mathrm{CD} 4^{+} \mathrm{CD} 25^{+}$counterparts. Importantly, the adoptive transfer of $\mathrm{CD}^{+} \mathrm{CD} 122^{+}$, but not $\mathrm{CD} 4^{+} \mathrm{CD} 25^{+}$, Tregs plus treatments with recombinant murine IL-15 significantly extended allograft survival even in immune competent wild-type mice (27). By contrast, the adoptive transfer of $\mathrm{CD} 4{ }^{+} \mathrm{CD} 25^{+}$Tregs, together with administration of recombinant IL-15, did not significantly suppress allograft rejection. We postulated that administering IL-15 promoted the expansion of transferred $\mathrm{CD} 8{ }^{+} \mathrm{CD} 122^{+}$Tregs, which in turn extended allograft survival. Krupnick et al. found that costimulatory blockade-mediated long-term allograft acceptance was dependent on the rapid infiltration of the lung graft by central memory $\mathrm{CD} 8^{+} \mathrm{T}$-cells and on their production of IFN $\gamma$, which in turn induced nitric oxide (NO) and inhibited alloimmune responses (25). Taken together, $\mathrm{CD} 8^{+} \mathrm{CD} 122^{+}$ Tregs with central memory phenotypes can regulate both autoimmunity and alloimmunity, suggesting an important role for $\mathrm{CD}^{+} \mathrm{CD} 122^{+}$Tregs in the modulation of pathogenic immune responses.

\section{Mechanisms Responsible for Immunosuppression Mediated by CD8 $^{+}{ }^{C D 122}{ }^{+}$Tregs}

Although $\mathrm{CD}^{+} \mathrm{CD} 122^{+}$Tregs have been shown to suppress both alloimmune and autoimmune responses in animal models, their mechanisms of action are not fully understood. Endharti et al. have shown that $\mathrm{CD}^{+} \mathrm{CD} 122^{+}$Tregs suppress proliferation of conventional $\mathrm{CD}^{+} \mathrm{T}$-cells by producing IL-10 in vitro (15). Later on, both IL-10 and TGF $\beta 1$ produced by memory $\mathrm{CD}^{+} \mathrm{CD} 122^{+}$ Tregs were reportedly responsible for their suppressive activities $(15,23,24,41)$, as shown in Figure 1. CD8 ${ }^{+} \mathrm{CD} 122^{+}$Tregs recognized conventional $\mathrm{T}$ cells via the interaction of $\mathrm{MHC}$ class I- $\alpha \beta$ TCR and suppressed T-cell function by producing IL-10 (41). We demonstrated that prolongation of allograft survival by IL-10-deficient $\mathrm{CD} 8^{+} \mathrm{CD} 122^{+}$Tregs was largely diminished (24). Interestingly, both PD-1 and CD28 signaling pathways on $\mathrm{CD}^{+} \mathrm{CD} 122^{+}$Tregs were required for their optimal production of IL-10 (24). Moreover, CD8 ${ }^{+} \mathrm{CD} 122^{+}$Tregs released both IFN $\gamma$ and TGF $\beta 1$ that suppressed CD $4^{+} \mathrm{T}$ cell activation (22). Krupnick et al. revealed that CCR7 expression on central memory CD8 ${ }^{+}$ T-cells was critical for the formation of stable synapses with antigen-presenting cells, which resulted in the production of IFN- $\gamma$. The latter in turn induced nitric oxide, which downregulated alloimmune responses and suppressed lung allograft rejection (25). Importantly, $\mathrm{CD} 8^{+} \mathrm{CD} 122^{+}$Tregs ameliorated EAE 


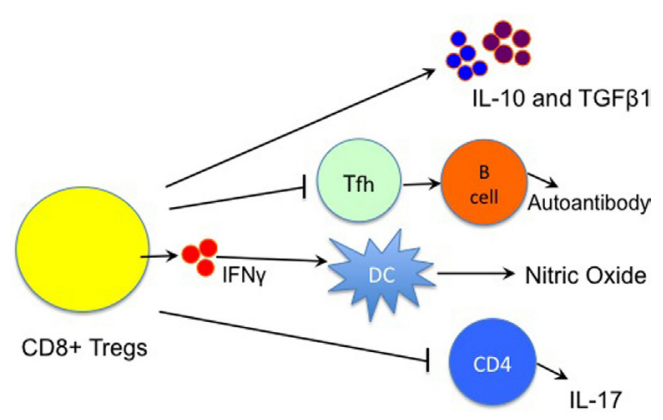

FIGURE 1 | Immune mechanisms underlying CD8 ${ }^{+}$CD122 ${ }^{+}$Treg suppression. $\mathrm{CD} 8{ }^{+} \mathrm{CD} 122^{+}$Treg suppression of immune responses is largely mediated by their production of IL-10 and TGF $\beta 1$, whereas IFN $\gamma$ also plays a role in the suppression by inducing the local production of nitric oxide (NO). They also inhibit the function of $\mathrm{T}$ follicular helper (Tfh) cells, resulting in the suppression of autoantibody production by B cells. Moreover, CD8 ${ }^{+} \mathrm{CD} 122^{+}$ Tregs suppress autoimmune responses via regulating IL-17 production by CD4+ T cells. (Lines with an arrow indicate "producing" or "promoting," whereas lines with a vertical bar imply "suppressing").

via inhibiting IL-17 production by $\mathrm{CD}^{+}$effector T-cells, and their suppressive function was dependent on IL-15 (38). On the other hand, disruption of the inhibitory interaction between $\mathrm{CD}^{+} \mathrm{CD} 122^{+} \mathrm{T}$-cells and their target $\mathrm{Qa}-1^{+}$follicular T-helper (Tfh) cells resulted in the development of a lethal systemic-lupuserythematosus-like autoimmune disease that was dependent on autoantibodies (42). Despite those findings, more studies are required to fully elucidate mechanisms underlying $\mathrm{CD} 8^{+} \mathrm{CD} 122^{+}$ Treg suppression. Fully understanding their mechanisms of action will help design effective approaches to treating allograft rejection and autoimmune diseases.

\section{Concluding Remarks}

Memory $\mathrm{CD}^{+} \mathrm{CD} 122^{+} \mathrm{T}$-cells have previously been considered to be antigen-specific memory T-cells (8-10). Especially, they exhibit central memory T-cell phenotypes. Mounting evidence has shown that they are also Tregs. Therefore, it is important to define how and when they act as memory versus Tregs. It has been known that abundant PD-1 expression on $\mathrm{CD}^{+} \mathrm{T}$-cells represents their status of exhaustion during chronic viral infection,

\section{References}

1. Zhai Y, Meng L, Gao F, Busuttil RW, Kupiec-Weglinski JW. Allograft rejection by primed/memory CD8+ T cells is CD154 blockade resistant: therapeutic implications for sensitized transplant recipients. J Immunol (2002) 169:46674673. doi:10.4049/jimmunol.169.8.4667

2. Trambley J, Bingaman AW, Lin A, Elwood ET, Waitze S-Y, Ha J, et al. Asialo GM1+ CD8+ T cells play a critical role in costimulation blockade-resistant allograft rejection. J Clin Invest (1999) 104:1715-1722. doi:10.1172/JCI8082

3. Adams AB, Williams MA, Jones TR, Shirasugi N, Durham MM, Kaech SM, et al. Heterologous immunity provides a potent barrier to transplantation tolerance. J Clin Invest (2003) 111:1887-1895. doi:10.1172/ JCI200317477 while PD-1 blockade restores their immune responses (43-46). Recent studies have also shown that $\mathrm{T}$ cells undergoing homeostatic proliferation consist of both $\mathrm{PD}-1^{+}$and $\mathrm{PD}-1^{-}$components. It was $\mathrm{PD}-1^{+}$subset of the T-cells that were dysfunctional (47). We have determined if $\mathrm{CD} 8^{+} \mathrm{CD} 122^{+} \mathrm{T}$-cells also contain both $\mathrm{PD}-1^{+}$and $\mathrm{PD}-1^{-}$subsets. We found that $\mathrm{CD} 8^{+} \mathrm{CD} 122^{+}$ T-cells contained a subset of $\mathrm{PD}-1^{+}$cell population that actually suppressed allograft rejection, while donor-specific $\mathrm{PD}-1^{-} \mathrm{CD} 8^{+} \mathrm{CD} 122^{+} \mathrm{T}$-cells were memory T-cells (24). Hence, PD-1 marker can be utilized to identify murine $\mathrm{CD} 8^{+} \mathrm{CD} 122^{+}$ Tregs. On the other hand, we have found that "bystander" central memory $\mathrm{CD}^{+} \mathrm{T}$-cells, which do not recognize a specific allograft, are true Tregs (23), whereas others have also shown that memory-like $\mathrm{CD} 122^{+} \mathrm{CD} 8{ }^{+} \mathrm{CD} 38^{+} \mathrm{T}$-cells suppress $\mathrm{CD} 4^{+}$ $\mathrm{T}$ cell activation in an antigen-independent fashion, indicating that $\mathrm{CD}^{+} \mathrm{CD} 122^{+}$Tregs act in an antigen-non-specific manner.

Murine $\mathrm{CD}^{+} \mathrm{CD} 122^{+}$Tregs are naturally arising and exhibit a distribution pattern of two age-related phases. It is unclear if they can be induced from naïve $\mathrm{CD}^{+} \mathrm{T}$-cells. Naturally occurring $\mathrm{CD} 8^{+} \mathrm{CD} 122^{+}$Tregs can suppress both autoimmunity and alloimmunity in many animal models of diseases. Mechanisms underlying $\mathrm{CD}^{+} \mathrm{CD} 122^{+}$Treg suppression mainly include their production of IL-10, TGF $\beta 1$, IFN $\gamma$, etc. Although IL-15 drives the homeostatic expansion of murine $\mathrm{CD}^{+} \mathrm{CD} 122^{+}$Tregs, it remains unknown what drives homeostatic proliferation of human $\mathrm{CD}^{+} \mathrm{CXCR} 3^{+}$ Tregs that do not express CD122, although both Tregs exhibit the phenotypes of central memory T-cells. Further studies are warranted to determine if human $\mathrm{CD} 8^{+} \mathrm{CXCR} 3^{+}$Tregs can exert suppressive function in vivo.

\section{Author Contributions}

JL collected literature and wrote a part of manuscript; DC and GDN edited the manuscript; and ZD wrote the review manuscript.

\section{Funding}

This work was supported by National Science Foundation of China (NSFC 81471550). 
7. Wu Z, Bensinger SJ, Zhang J, Chen C, Yuan X, Huang X, et al. Homeostatic proliferation is a barrier to transplantation tolerance. Nat Med (2003) 10:87-92. doi:10.1038/nm965

8. Zhang X, Sun S, Hwang I, Tough DF, Sprent J. Potent and selective stimulation of memory-phenotype CD8+ T cells in vivo by IL-15. Immunity (1998) 8:591-599. doi:10.1016/S1074-7613(00)80564-6

9. Ku CC, Murakami M, Sakamoto A, Kappler J, Marrack P. Control of homeostasis of CD8+ memory T cells by opposing cytokines. Science (2000) 288:675-678. doi:10.1126/science.288.5466.675

10. Judge AD, Zhang X, Fujii H, Surh CD, Sprent J. Interleukin 15 controls both proliferation and survival of a subset of memory-phenotype CD8(+) T cells. J Exp Med (2002) 196:935-946. doi:10.1084/jem.20020772

11. Gershon RK, Kondo K. Cell interactions in the induction of tolerance: the role of thymic lymphocytes. Immunology (1970) 18:723-737.

12. Cantor H, Shen FW, Boyse EA. Separation of helper T cells from suppressor $\mathrm{T}$ cells expressing different Ly components. II. Activation by antigen: after immunization, antigen-specific suppressor and helper activities are mediated by distinct T-cell subclasses. J Exp Med (1976) 143:1382-1390. doi:10.1084/ jem.143.6.1391

13. Lu L, Cantor H. Generation and regulation of CD8(+) regulatory T cells. Cell Mol Immunol (2008) 5:401-406. doi:10.1038/cmi.2008.50

14. Rifa'i M, Kawamoto Y, Nakashima I, Suzuki H. Essential roles of CD8+CD122+ regulatory T cells in the maintenance of T cell homeostasis. J Exp Med (2004) 200:1123-1134. doi:10.1084/jem.20040395

15. Endharti AT, Rifa IM, Shi Z, Fukuoka Y, Nakahara Y, Kawamoto Y, et al. Cutting edge: CD8+CD122+ regulatory $\mathrm{T}$ cells produce IL-10 to suppress IFN-gamma production and proliferation of CD8+ T cells. J Immunol (2005) 175:7093-7097. doi:10.4049/jimmunol.175.11.7093

16. Chen X, Priatel JJ, Chow MT, Teh HS. Preferential development of CD4 and CD8 T regulatory cells in RasGRP1-deficient mice. J Immunol (2008) 180:5973-5982. doi:10.4049/jimmunol.180.9.5973

17. Shi Z, Rifải M, Lee YH, Shiku H, Isobe K, Suzuki H. Importance of CD80/CD86-CD28 interactions in the recognition of target cells by CD8+CD122+ regulatory $\mathrm{T}$ cells. Immunology (2008) 124:121-128. doi:10.1111/j.1365-2567.2007.02747.x

18. Molloy MJ, Zhang W, Usherwood EJ. Suppressive CD8+ T cells arise in the absence of CD4 help and compromise control of persistent virus. J Immunol (2011) 186:6218-6226. doi:10.4049/jimmunol.1003812

19. Endharti AT, Okuno Y, Shi Z, Misawa N, Toyokuni S, Ito M, et al. $\mathrm{CD} 8+\mathrm{CD} 122+$ regulatory $\mathrm{T}$ cells (Tregs) and CD4+ Tregs cooperatively prevent and cure CD4+ cell-induced colitis. J Immunol (2011) 186:41-52. doi:10.4049/jimmunol.1000800

20. Wang LX, Li Y, Yang G, Pang PY, Haley D, Walker EB, et al. CD122+CD8+ Treg suppress vaccine-induced antitumor immune responses in lymphodepleted mice. Eur J Immunol (2010) 40:1375-1385. doi:10.1002/ eji.200839210

21. Kim HJ, Wang X, Radfar S, Sproule TJ, Roopenian DC, Cantor H. CD8+ T regulatory cells express the Ly49 Class I MHC receptor and are defective in autoimmune prone B6-Yaa mice. Proc Natl Acad Sci U S A (2011) 108:20102015. doi:10.1073/pnas.1018974108

22. Mangalam AK, Luckey D, Giri S, Smart M, Pease LR, Rodriguez M, et al. Two discreet subsets of CD8 T cells modulate PLP(91-110) induced experimental autoimmune encephalomyelitis in HLA-DR3 transgenic mice. J Autoimmun (2012) 38:344-353. doi:10.1016/j.jaut.2012.02.004

23. Wan N, Dai H, Wang T, Moore Y, Zheng XX, Dai Z. Bystander central memory but not effector memory CD8+ T cells suppress allograft rejection. J Immunol (2008) 180:113-121. doi:10.4049/jimmunol.180.1.113

24. Dai H, Wan N, Zhang S, Moore Y, Wan F, Dai Z. Cutting edge: programmed death-1 defines CD8+CD122+ T cells as regulatory versus memory $\mathrm{T}$ cells. J Immunol (2010) 185:803-807. doi:10.4049/jimmunol.1000661

25. Krupnick AS, Lin X, Li W, Higashikubo R, Zinselmeyer BH, Hartzler H, et al. Central memory CD8+ T lymphocytes mediate lung allograft acceptance. J Clin Invest (2014) 124:1130-1143. doi:10.1172/JCI71359

26. Sakaguchi S, Sakaguchi N, Asano M, Itoh M, Toda M. Immunological self-tolerance maintained by activated T cells expressing IL-2 receptor alpha-chains (CD25)-breakdown of a single mechanism of self-tolerance causes various autoimmune diseases. J Immunol (1995) 155:1151-1164.
27. Dai Z, Zhang S, Xie Q, Wu S, Su J, Li S, et al. Natural CD8+CD122+ T cells are more potent in suppression of allograft rejection than CD4+CD25+ regulatory T cells. Am J Transplant (2014) 14:39-48. doi:10.1111/ajt.12515

28. Suzuki H, Shi Z, Okuno Y, Isobe K. Are CD8+CD122+ cells regulatory T cells or memory T cells? Hum Immunol (2008) 69:751-754. doi:10.1016/j. humimm.2008.08.285

29. Lerret NM, Houlihan JL, Kheradmand T, Pothoven KL, Zhang ZJ, Luo X. Donor-specific CD8+ Foxp3+ $\mathrm{T}$ cells protect skin allografts and facilitate induction of conventional CD4+ Foxp3+ regulatory T cells. Am J Transplant (2012) 12:2335-2347. doi:10.1111/j.1600-6143.2012.04120.x

30. Bahri R, Bollinger A, Bollinger T, Orinska Z, Bulfone-Paus S. Ectonucleotidase CD38 demarcates regulatory, memory-like CD8+ T cells with IFN-gammamediated suppressor activities. PLoS One (2012) 7(9):e45234. doi:10.1371/ journal.pone.0045234.

31. Shi Z, Okuno Y, Rifải M, Endharti AT, Akane K, Isobe K, et al. Human $\mathrm{CD} 8+\mathrm{CXCR} 3+\mathrm{T}$ cells have the same function as murine CD8+CD122+ Treg. Eur J Immunol (2009) 39:2106-2119. doi:10.1002/eji.200939314

32. Kennedy MK, Glaccum M, Brown SN, Butz EA, Viney JL, Embers M, et al. Reversible defects in natural killer and memory CD8 T cell lineages in interleukin-15-deficient mice. J Exp Med (2000) 191:771-780. doi:10.1084/ jem.191.5.771

33. Lodolce JP, Boone DL, Chai S, Swain RE, Dassopoulos T, Trettin S, et al. IL-15 receptor maintains lymphoid homeostasis by supporting lymphocyte homing and proliferation. Immunity (1998) 9:669-676. doi:10.1016/ S1074-7613(00)80664-0

34. Sneller MC, Kopp WC, Engelke KJ, Yovandich JL, Creekmore SP, Waldmann TA, et al. IL-15 administered by continuous infusion to rhesus macaques induces massive expansion of $\mathrm{CD} 8+\mathrm{T}$ effector memory population in peripheral blood. Blood (2011) 118:6845-6848. doi:10.1182/ blood-2011-09-377804

35. Yu P, Steel JC, Zhang M, Morris JC, Waitz R, Fasso M, et al. Simultaneous inhibition of two regulatory T-cell subsets enhanced Interleukin-15 efficacy in a prostate tumor model. Proc Natl Acad Sci U S A (2012) 109:6187-6192. doi:10.1073/pnas.1203479109

36. Okuno Y, Murakoshi A, Negita M, Akane K, Kojima S, Suzuki H. CD8+ $\mathrm{CD} 122+$ regulatory $\mathrm{T}$ cells contain clonally expanded cells with identical CDR3 sequences of the T-cell receptor beta-chain. Immunology (2013) 139:309-317. doi:10.1111/imm.12067

37. Lee YH, Ishida Y, Rifa'i M, Shi Z, Isobe K, Suzuki H. Essential role of $\mathrm{CD} 8+\mathrm{CD} 122+$ regulatory $\mathrm{T}$ cells in the recovery from experimental autoimmune encephalomyelitis. J Immunol (2008) 180:825-832. doi:10.4049/ jimmunol.180.2.825

38. Yu P, Bamford RN, Waldmann TA. IL-15-dependent CD8+ CD122+ T cells ameliorate experimental autoimmune encephalomyelitis by modulating IL-17 production by CD4+ T cells. Eur JImmunol (2014) 44:3330-3341. doi:10.1002/eji.201444675

39. Zozulya AL, Ortler S, Fabry Z, Sandor M, Wiendl H. The level of B7 homologue 1 expression on brain DC is decisive for CD8 Treg cell recruitment into the CNS during EAE. Eur J Immunol (2009) 39:1536-1543. doi:10.1002/eji.200839165

40. Saitoh O, Abiru N, Nakahara M, Nagayama Y. CD8+CD122+ T cells, a newly identified regulatory $\mathrm{T}$ subset, negatively regulate Graves' hyperthyroidism in a murine model. Endocrinology (2007) 148:6040-6046. doi:10.1210/ en.2007-0300

41. Rifải M, Shi Z, Zhang SY, Lee YH, Shiku H, Isobe K, et al. CD8+CD122+ regulatory $\mathrm{T}$ cells recognize activated $\mathrm{T}$ cells via conventional MHC class I-alphabetaTCR interaction and become IL-10-producing active regulatory cells. Int Immunol (2008) 20:937-947. doi:10.1093/intimm/dxn052

42. Kim HJ, Verbinnen B, Tang X, Lu L, Cantor H. Inhibition of follicular T-helper cells by CD $8(+)$ regulatory T cells is essential for self tolerance. Nature (2010) 467:328-332. doi:10.1038/nature09370

43. Velu V, Titanji K, Zhu B, Husain S, Pladevega A, Lai L, et al. Enhancing SIVspecific immunity in vivo by PD-1 blockade. Nature (2009) 458:206-210. doi:10.1038/nature07662

44. Blackburn SD, Shin H, Haining WN, Zou T, Workman CJ, Polley A, et al. Coregulation of CD8+ $\mathrm{T}$ cell exhaustion by multiple inhibitory receptors during chronic viral infection. Nat Immunol (2009) 10:29-37. doi:10.1038/ ni. 1679 
45. Barber DL, Wherry EJ, Masopust D, Zhu B, Allison JP, Sharpe AH, et al. Restoring function in exhausted CD8 T cells during chronic viral infection. Nature (2006) 439:682-687. doi:10.1038/nature04444

46. Petrovas C, Casazza JP, Brenchley JM, Price DA, Gostick E, Adams WC, et al. PD-1 is a regulator of virus-specific CD8+ T cell survival in HIV infection. J Exp Med (2006) 203:2281-2292. doi:10.1084/jem.20061496

47. Lin SJ, Peacock CD, Bahl K, Welsh RM. Programmed death-1 (PD-1) defines a transient and dysfunctional oligoclonal $\mathrm{T}$ cell population in acute homeostatic proliferation. J Exp Med (2007) 204:2321-2333. doi:10.1084/ jem. 20062150
Conflict of Interest Statement: The authors declare that the research was conducted in the absence of any commercial or financial relationships that could be construed as a potential conflict of interest.

Copyright $\odot 2015$ Liu, Chen, Nie and Dai. This is an open-access article distributed under the terms of the Creative Commons Attribution License (CC BY). The use, distribution or reproduction in other forums is permitted, provided the original author(s) or licensor are credited and that the original publication in this journal is cited, in accordance with accepted academic practice. No use, distribution or reproduction is permitted which does not comply with these terms. 